\title{
The MicroRNA-23a Has Limited Roles in Bone Formation and Homeostasis In Vivo
}

\author{
J. PARK ${ }^{1,2^{*}}$, S. WADA $^{\mathbf{1}^{*}}$, T. USHIDA ${ }^{1}$, T. AKIMOTO ${ }^{1}$
}

* These authors contributed equally to this work.

${ }^{1}$ Division of Regenerative Medical Engineering, Center for Disease Biology and Integrative Medicine, Graduate School of Medicine, University of Tokyo, Tokyo, Japan, ${ }^{2}$ Department of Physical Education, Konkuk University, Seoul, Korea

Received August 28, 2014

Accepted January 7, 2015

On-line March 24, 2015

\begin{abstract}
Summary
Recent studies have demonstrated that some microRNAs (miRNAs) inhibit bone formation by inhibiting the translation of specific genes. Several in vitro studies have suggested that miR23a inhibits osteogenic differentiation by suppressing the translation of Runx2, a transcription factor essential for osteoblastogenesis, and of Satb2, a member of the special AT-rich binding protein family. In the present study, we used a gain-of-function approach to determine the roles of miR-23a in bone formation and homeostasis in vivo. The miR-23a transgenic $\mathrm{Tg}$ ) mice grew normally and their body size and weight were similar to those of wild-type (WT) littermates. Bone structure and morphology were similar in $\mathrm{Tg}$ and WT mice. Furthermore, the numbers of osteoblasts and osteoclasts, as well as their activities in bone were similar between $\mathrm{Tg}$ and WT mice. Our results indicate that miR-23 has limited roles in bone formation and maintenance in vivo in mice.
\end{abstract}

\section{Key words}

Non-coding RNA • Runx2 • Satb2 • Micro-CT

\section{Corresponding author}

T. Akimoto, Division of Regenerative Medical Engineering, Center for Disease Biology and Integrative Medicine, Graduate School of Medicine, The University of Tokyo, 7-3-1 Hongo, Bunkyo, Tokyo 113-0033, Japan. Fax: +81-3-5800-9199. E-mail: akimoto@m.u-tokyo.ac.jp

\section{Introduction}

Bone formation and maintenance are tightly regulated by osteogenic signaling pathways and several transcription factors, which induce bone-specific transactivation of certain genes (Soltanoff et al. 2009). Several studies have provided insight into the posttranscriptional regulation of bone formation (Gaur et al. 2010) and osteogenic differentiation (Hassan et al. 2010, Zhang et al. 2011) by microRNAs (miRNAs).

miRNAs are small noncoding RNAs that regulate the translation of genes encoding proteins in higher organisms. miRNAs are involved in almost every biological process, including development, growth, differentiation, cell death, and homeostasis (Bartel 2009). It was predicted that there are about 2,000 miRNAs in humans. The identification of miRNAs associated with skeletal abnormalities has allowed the development of new approaches that can help us to understand bone homeostasis and to treat diseases (Li et al. 2009, Lian et al. 2012).

Mice with limb- or cartilage-specific deletion of the miRNA-processing enzyme Dicer exhibited a severe phenotype with reduced limb size but normal patterning (Harfe et al. 2005, Kobayashi et al. 2008). In addition, bone-specific deletion of Dicer resulted in a high bone mass phenotype (Gaur et al. 2010). These findings suggest that miRNAs play critical roles in bone formation and maintenance. However, the specific miRNA that regulates bone formation and maintenance has not been identified.

Several miRNAs were reported to regulate osteogenesis in studies using in vitro models of osteogenic differentiation (Li et al. 2009, Hassan et al. 
2010). In particular, Hassan et al. (2010) reported that miR-23a inhibits Runx2 and Satb2 translation in terminally differentiated osteocytes, representing a possible feedback mechanism to attenuate osteoblast maturation (Hassan et al. 2010).

Although it is well established that miR-23a is involved in osteogenic differentiation in vitro, its roles in bone formation and in the regulation of bone turnover in the adult skeleton in vivo, are unknown. To address this issue, and to provide insight into the in vivo function of miR-23a in bone formation and homeostasis, we generated transgenic (Tg) mice overexpressing miR-23a. We used a gain-of-function approach to examine whether overexpression of miR-23a affects bone formation and maintenance in vivo.

\section{Materials and Methods}

\section{Animal experiments}

Adult (8-week-old) male C57BL/6 mice (Clea Japan, Inc., Tokyo, Japan) and miR-23a Tg mice were housed in a temperature-controlled room $\left(21^{\circ} \mathrm{C}\right)$ with a $12 \mathrm{~h}$ light/12 $\mathrm{h}$ dark cycle, and were provided with food and water ad libitum. The animal protocol was approved by the Animal Care and Use Committee of the University of Tokyo.

\section{Generation of Tg mice}

The miR-23a Tg mice were generated as previously described (Wada et al. 2011). Briefly, pCXbG-miR-23a was linearized using SalI-EcoRI sites and was injected into C57BL6/J oocytes. Genotyping was carried out by polymerase chain reaction (PCR). Fluorescence microscopy was performed to confirm transgene expression in adult tissues. Tissue samples were harvested from the F2-3 generation of Tg mice and wild-type (WT) littermates (C57BL6/J background) at 8 weeks of age.

\section{MicroRNA analysis}

The TaqMan MicroRNA Reverse Transcription Kit and TaqMan MicroRNA assays (Applied Biosystems, Foster City, CA) were used for real-time PCR quantification of mature miRNA expression. Briefly, mature miR-23a was reverse-transcribed with specific reverse-transcription (RT) primers, quantified with a TaqMan probe, and normalized by U6 small nuclear RNA using TaqMan miRNA assays.
Total RNA (500 ng) was reverse-transcribed using specific RT primers for pri-miR-23a and ThermoScript RT (Invitrogen, Carlsbad, CA), as previously reported (Jiang et al. 2005). Briefly, $500 \mathrm{ng}$ of total RNA, $1 \mu \mathrm{l}$ of $10 \mu \mathrm{M}$ oligo-dT primer, and $2 \mu \mathrm{l}$ of $10 \mathrm{mM}$ dNTP were mixed and distilled water was added to a total volume of $12 \mu \mathrm{l}$. The mixture was heated at $85^{\circ} \mathrm{C}$ for $5 \mathrm{~min}$ and $57^{\circ} \mathrm{C}$ for $5 \mathrm{~min}$. After chilling on ice for $2 \mathrm{~min}, 4 \mu \mathrm{l}$ of $5 \times$ cDNA synthesis buffer, and $1 \mu \mathrm{l}$ each of 0.1 M DTT, RNase inhibitor (ToYoBo, Osaka, Japan), and ThermoScript RT (15 U/ $\mu$ l) were added to the mixture. The contents were gently mixed and incubated at $57^{\circ} \mathrm{C}$ for $60 \mathrm{~min}$, and were heated at $85^{\circ} \mathrm{C}$ for $5 \mathrm{~min}$ to terminate the reaction. To quantify pri-miR-23a, $1 \mu \mathrm{l}$ of the RT product was amplified by PCR using Ex Taq HS (TaKaRa Bio, Shiga, Japan) in a total reaction volume of $50 \mu \mathrm{l}$ using the following primers: forward 5'-AGC AAG AAT GCT CCA ATC TCA-3' and reverse 5'-TGG TAA TCC CTG GCA ATG TG-3'. The PCR conditions for pre-miR-23a consisted of 34 cycles of denaturation at $98^{\circ} \mathrm{C}$ for $10 \mathrm{~s}$, annealing at $57{ }^{\circ} \mathrm{C}$ for $15 \mathrm{~s}$, and extension at $72{ }^{\circ} \mathrm{C}$ for $15 \mathrm{~s}$. The PCR products were electrophoresed on $2 \%$ agarose gels containing $0.00005 \%$ ethidium bromide for $30 \mathrm{~min}$. Fluorescent images were acquired under ultraviolet light using an LAS3000 imager (FujiFilm Corp., Tokyo, Japan).

\section{Micro-computed tomography of trabecular and cortical bone}

Bone morphology and microarchitecture were assessed by high-resolution micro-computed tomography ( $\mu \mathrm{CT}$ ) (inspeXio SMX-90CT; Shimadzu, Tokyo, Japan) as previously described (Harada et al. 2011). The proximal tibia and diaphysial tibia were scanned at an X-ray energy of $70 \mathrm{keV}$, with an integration time of $0.12 \mathrm{~s}$ and voxel size of $0.025 \mathrm{~mm} / \mathrm{pix}$. Threedimensional (3D) reconstruction of mineralized tissue was performed using the TRI-BONE system (Ratoc System Engineering, Co., Ltd., Tokyo, Japan).

For the trabecular bone region of the proximal tibia, we determined trabecular bone volume (BV/TV, $\%$ ), trabecular thickness (Tb.Th, $\mu \mathrm{m})$, trabecular number (Tb.N, 1/mm), trabecular separation (Tb.Sp, mm), and structure model index (SMI) (Hildebrand and Rüegsegger 1997). For the cortical bone region in the tibial diaphysis, we assessed medullary volume/total bone volume (MV/TV, \%), cortical bone volume/total bone volume (CV/TV), and cortical thickness (Ct.Th, $\mu \mathrm{m})$. 


\section{$\operatorname{miR}-23 a$}

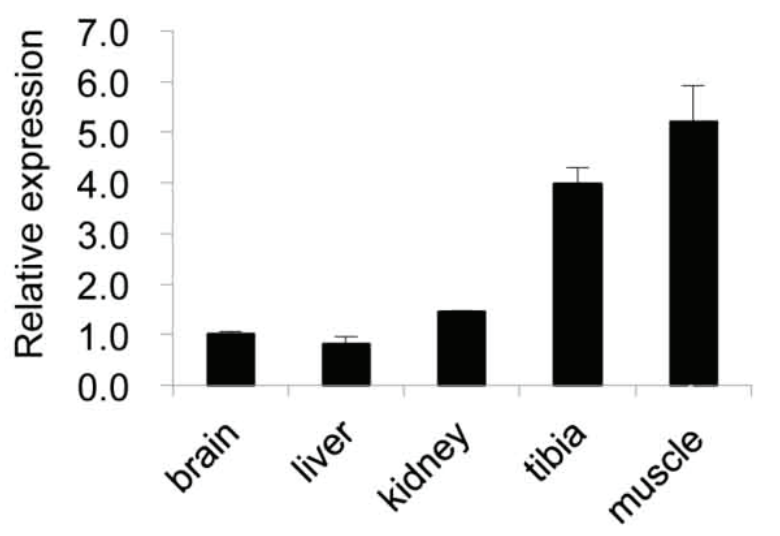

miR-23b

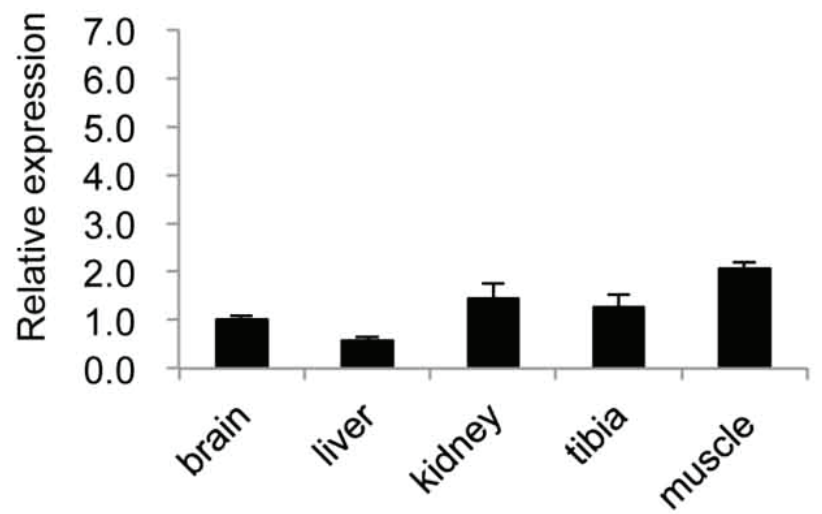

Fig. 1. Expression of miR-23a and mIR-23b in brain, liver, kidney, tibia, and muscle of miR-23a $\mathrm{Tg}$ and WT mice. The expression levels of mature miR-23a and miR-23b were measured by real-time TaqMan RT-PCR, and were normalized to the expression of U6 with the $2^{-\Delta \Delta \mathrm{Ct}}$ cycle threshold method. Values are presented relative to the expression level in brain. Data are presented as the mean $\pm \mathrm{SEM}$ $(n=3) . \mathrm{Tg}$, miR-23a transgenic mice; WT, wild-type mice

\section{Histology and quantitative histomorphometry}

Femoral width and length was measured using calipers. Femoral length was measured from greater trochanter to medial condyle. Femoral width was measured at the point of the half of femoral length. Quantitative histologic analysis, and quantitative static and dynamic histomorphometry were assessed as previously described (Hiruma et al. 2013). The histomorphometric measurements of the secondary spongiosa of the proximal tibia included trabecular BV/TV, Tb.Th, Tb.N, Tb.Sp, eroded surface/bone surface (ES/BS, \%), osteoid surface/bone surface (OS/BS, \%), osteoblast surface/bone surface (Ob.S/BS, \%), osteoclast surface/bone surface (Oc.S/BS, \%), osteoblast number/bone surface (Ob.N/BS, $\mathrm{mm}^{-1}$ ), osteoclast number/bone surface (Oc.N/BS, $\mathrm{mm}^{-1}$ ), and multiple osteoclast number/bone surface (Mu.Oc.N/BS, $\mathrm{mm}^{-1}$ ).

Measurement of alkaline phosphatase (ALP) and tartrate-resistant acid phosphatase (TRAP) activities

ALP and TRAP activities were measured as previously described with minor modifications (Bessey et al. 1946, Lau et al. 1987). After completely removing the bone marrow and blood from the cortical region of the femur, the bone fragments were grinded in a mortar on dry ice and homogenized in a buffer consisting of $10 \mathrm{mM}$ 2-amino-2-hydroxymethyl-1,3-propanediol, $0.9 \% \mathrm{NaCl}$, and $1 \%$ Triton $\mathrm{X}-100$. After centrifugation, the protein content of the supernatant was determined by the Lowry method (Lowry et al. 1951).

ALP activity was determined as the release of $p$-nitrophenol ( $p$ NP) from $p$-nitrophenol phosphate $(p \mathrm{NPP})$. First, $1 \mathrm{ml}$ of a mixture of $10 \mathrm{mM} p \mathrm{NPP}$, $100 \mathrm{mM}$ 2-amino-2-methyl 1,3-propanediol-HCl (pH 10.0), and $5 \mathrm{mM} \mathrm{MgCl} 1_{2}$ was incubated at $37^{\circ} \mathrm{C}$. Then, $10 \mu \mathrm{l}$ of the extracted protein was added and incubated at $37^{\circ} \mathrm{C}$ for $10 \mathrm{~min}$, followed by the addition of $66 \mu \mathrm{l}$ of $1 \mathrm{~N}$ $\mathrm{NaOH}$ to stop the reaction.

TRAP activity was determined using $10 \mathrm{mM}$ pNPP in citrate buffer ( $\mathrm{pH} 5.5$ ) containing $200 \mathrm{mM} \mathrm{NaCl}$ and $80 \mathrm{mM} \mathrm{L}(+)-\mathrm{Na}_{2} \mathrm{C}_{4} \mathrm{H}_{4} \mathrm{O}_{6}$. Samples were incubated at $37^{\circ} \mathrm{C}$ for $60 \mathrm{~min}$ and $66 \mu \mathrm{l}$ of $1 \mathrm{~N} \mathrm{NaOH}$ was added to stop the reaction.

In both assays, the absorbance was measured (ARVO MX; PerkinElmer, Waltham, MA) at $405 \mathrm{~nm}$. ALP and TRAP activities for each sample were calculated using a $p$ NP standard curve and were normalized to the total protein concentration.

\section{Statistics}

Data are presented as the mean \pm standard error. Statistical significance $(P<0.05)$ was determined by Student's $t$-test for comparisons between two groups or by analysis of variance followed by Dunnett's test for comparisons between multiple groups.

\section{Results}

\section{Tissue expression of miR-23}

We first measured expression levels of miR-23a and miR-23b in various tissues from Tg mice (Fig. 1). Skeletal muscle had the highest expression level of miR- 
$23 \mathrm{a}$ of all tissues tested. The expression level of miR-23a was higher in bone than in brain, liver, or kidney. Skeletal muscle also had the highest expression level of miR-23b, but the differences in miR-23b expression levels among the tissues were quite small. These results suggest that miR-23a has some roles in bone.

A

$\operatorname{miR}-23 a$

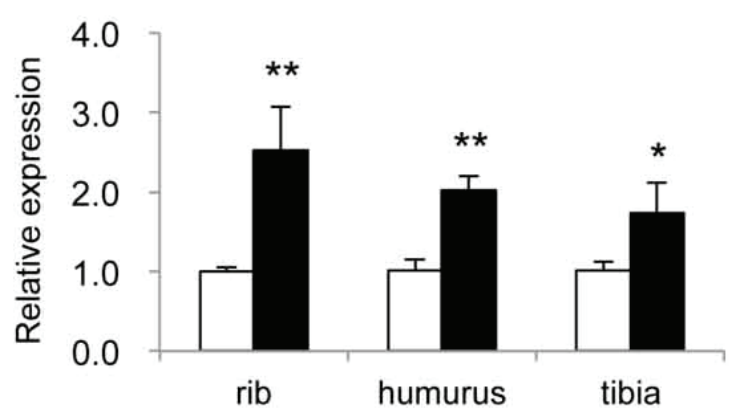

$\operatorname{miR}-23 b$

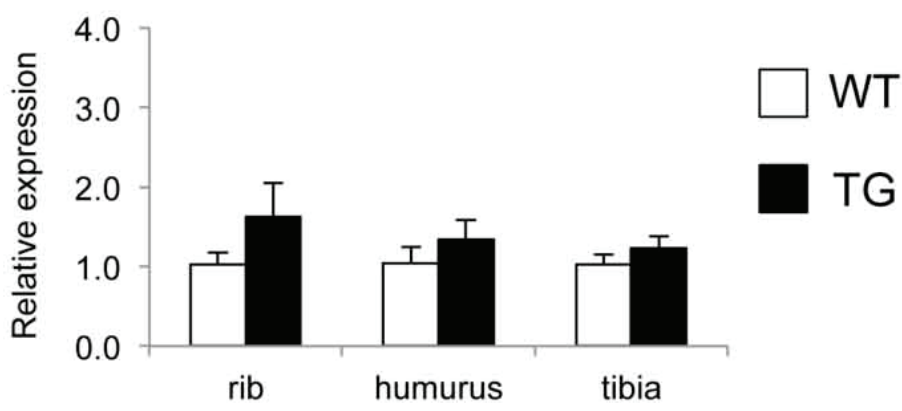

B

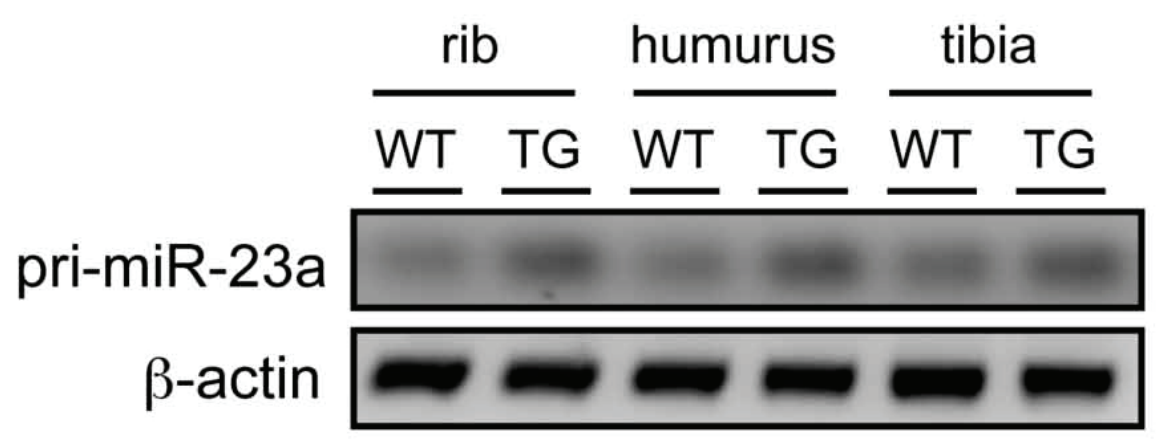

Fig. 2. Expression of miR-23a in the bones of miR-23a $\mathrm{Tg}$ mice. (A) The expression levels of mature miR-23a and miR-23b were measured by real-time TaqMan RT-PCR. (B) Precursor miR-23a (pre-miR-23a) was quantified by semi-quantitative PCR $(n=4)$. Values are relative to the expression in the rib of WT mice. $* P<0.05$ and $* * P<0.01$ vs. WT mice. Data are presented as the mean \pm SEM ( $n=4-5) . \mathrm{Tg}$, miR-23a transgenic mice; WT, wild-type mice

\section{Skeletal growth in miR-23a Tg mice}

The expression of mature miR-23a in bone was about 2 times higher in Tg mice than in WT littermates, whereas the expression of mature miR-23b was not significantly different between these genotypes (Fig. 2A). We confirmed that the expression of primary miR-23a (pri-miR-23a) was also increased in Tg mice (Fig. 2B). The Tg mice were born in normal Mendelian ratios and were fertile. The skeletal development of $\mathrm{Tg}$ mice during embryogenesis was macroscopically normal (data not shown). Postnatally, the Tg mice grew normally, and their body size and weight were similar to those of WT littermates. The bone weight and bone length were also similar between the two genotypes (Fig. 3A). Femur width was not significantly different between Tg and WT mice (Fig. 3A).

\section{Bone morphology of Tg mice}

We next assessed the bone morphology and microarchitecture of $\mathrm{Tg}$ mice using $\mu \mathrm{CT}$. We scanned the proximal and diaphysial tibia, and determined BV/TV, Tb.Th, Tb.N, MV/TV, CV/TV, and Ct.Th. The results are shown in Figure $3 \mathrm{~B}$ and $3 \mathrm{C}$. The cortical bone and total bone volumes in WT mice were $0.21 \pm 0.03$ and $0.21 \pm 0.04 \mathrm{~mm}^{3}$, respectively, while those in $\mathrm{Tg}$ mice were $0.32 \pm 0.05$ and $0.33 \pm 0.05 \mathrm{~mm}^{3}$, respectively. The SMI was $2.34 \pm 0.66$ and $2.90 \pm 0.07$ in WT and Tg mice, respectively. There were no significant differences in any bone morphologic factors between Tg and WT mice. 
A

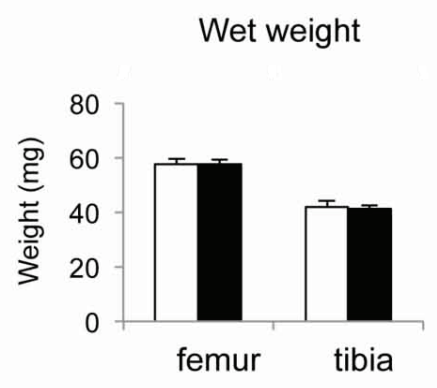

Bone length

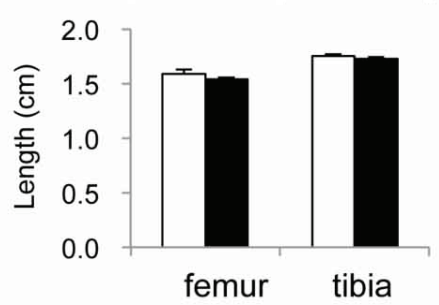

Femur width

B
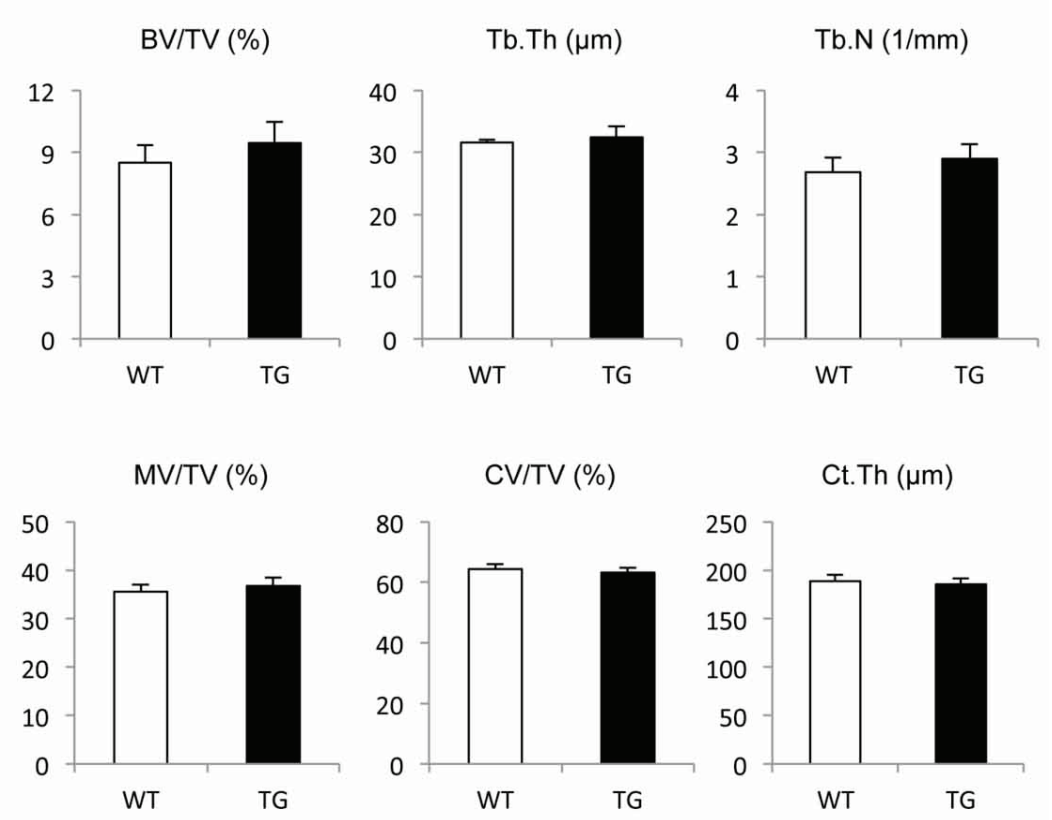

C

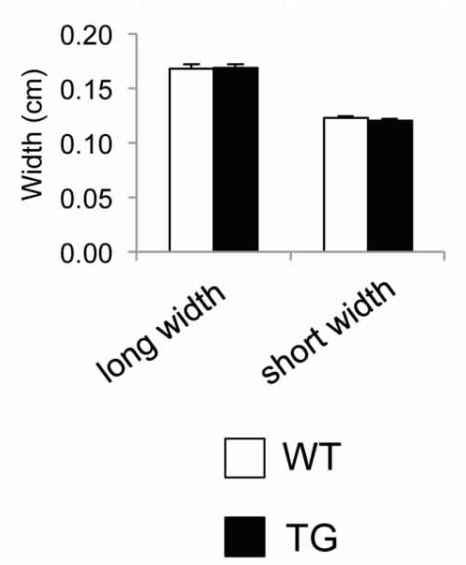

WT

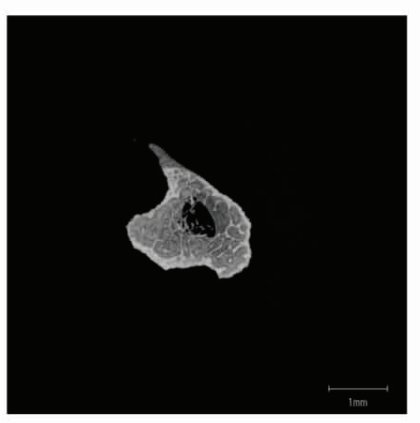

TG

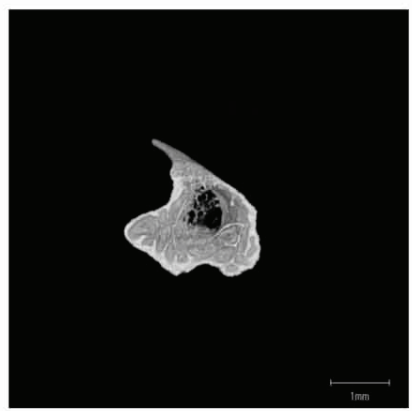

Fig. 3. Bone morphology of miR-23a Tg mice. (A) Bone weight, bone length, and femur width in $\mathrm{Tg}$ and WT mice. (B) Bone morphology and microarchitecture were assessed by $\mu \mathrm{CT}$. (C) Representative $\mu \mathrm{CT}$ images of the proximal tibia in WT and Tg mice. Data are presented as the mean \pm SEM $(n=5-6)$. Tg, miR-23a transgenic mice; WT, wild-type mice; BV/TV, trabecular bone volume/total bone volume; Tb.Th, trabecular thickness; Tb.N, trabecular number; MV/TV, medullary volume/total bone volume; CV/TV, cortical bone volume/total bone volume; Ct.Th, cortical thickness

\section{Histomorphometry of Tg mice}

We next assessed whether overexpression of miR-23a affected the histomorphometric characteristics of bone (Fig. 4A, B). The histomorphometric measurements of the secondary spongiosa of the proximal tibia revealed no differences in the parameters BV/TV, Tb.Th, Tb.N, Tb.Sp, ES/BS, OS/BS, Ob.S/BS, Oc.S/BS, Ob.N/BS, Oc.N/BS, or Mu.Oc.N/BS between Tg and WT mice (Fig. 4A, B).

\section{Osteoblast and osteoclast activities in Tg mice}

We finally assessed osteoblast and osteoclast activities in Tg mice. As shown in Figure 5, there were no differences in ALP or TRAP activities between Tg and WT mice.

\section{Discussion}

The present results show that miR-23a-mediated control of gene expression has limited roles in bone formation and homeostasis in vivo, based on the morphology, microarchitecture, and histology of bone in miR-23a Tg mice. 
A

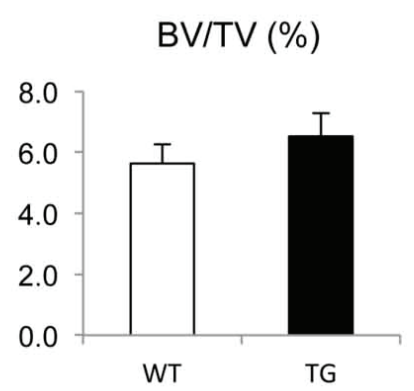

$\operatorname{Tb} . T h(\mu \mathrm{m})$

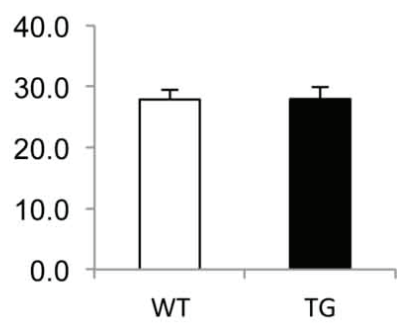

OV/TV $(\%)$

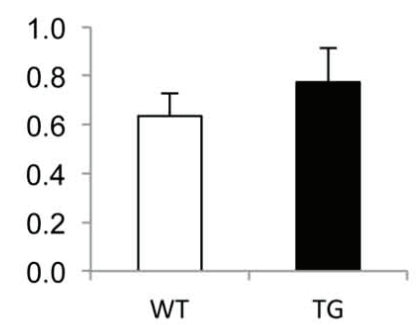

B

Ob.S/BS (\%)

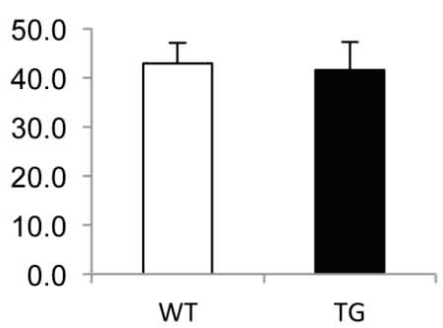

Oc.S/BS (\%)

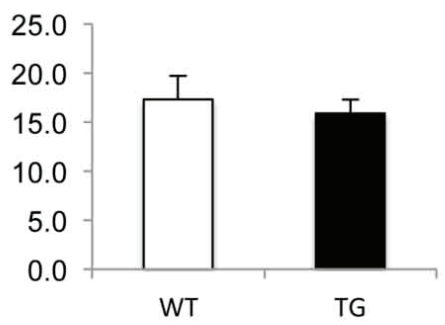

Mu.Oc.N/BS $\left(\mathrm{mm}^{-1}\right)$

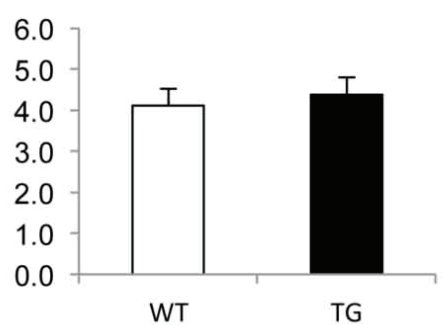

Fig. 4. Bone histochemistry of miR-23a $\mathrm{Tg}$ mice. Bone morphology and microarchitecture were assessed histologically. Data are presented as the mean \pm SEM $(n=5-6)$. Tg, miR-23a transgenic mice; WT, wild-type mice; BV/TV, bone volume/total volume fraction; Tb.Th, trabecular thickness; Tb.N, trabecular number; Tb.Sp, trabecular separation; ES/BS, eroded surface/bone surface; OS/BS, osteoid surface/bone surface; Ob.S/BS, osteoblast surface/bone surface; Oc.S/BS, osteoclast surface/bone surface; Ob.N/BS, osteoblast number/bone surface; Oc.N/BS, osteoclast number/bone surface

ALP

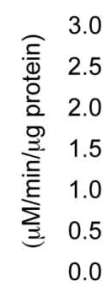

0.0

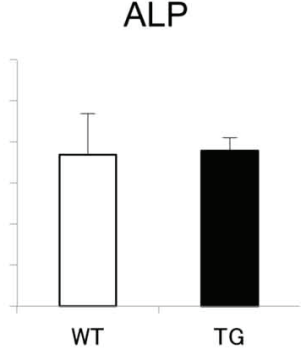

TRAP

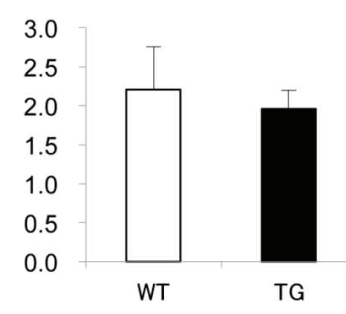

Fig. 5. Osteoblast and osteoclast activities in miR-23a $\mathrm{Tg}$ mice. ALP and TRAP activities were measured by colorimetric assays. Data are presented as the mean \pm SEM $(n=5-6)$. Tg, miR-23a transgenic mice; WT, wild-type mice; ALP, alkaline phosphatase; TRAP, tartrate-resistant acid phosphatase
Several in vitro studies have shown that miR-23a suppresses the protein expression of Runx2 and Satb2 by directly binding to their 3' untranslated regions (Hassan et al. 2010, Zhang et al. 2011). According to these earlier observations, we hypothesize that overexpression of miR23a in mice would delay osteocyte maturation in the mineralized matrix and would adversely affect bone structure, including its architecture, morphology, and histology. However, contrary to our original hypothesis, we found that the bone morphology of miR-23a Tg mice was normal, and was similar to that of their WT littermates. Furthermore, the histological analysis showed that the numbers of osteoblasts and osteoclasts, as well as their activities, were similar in both genotypes. These 
findings indicate that miR-23a plays limited roles in bone formation and homeostasis in vivo.

Runx2 is a runt-related transcription factor that is involved in the earliest stages of bone formation. Runx 2 is also expressed in pre-chondrocytes (Enomoto et al. 2000). In humans, a mutation in one allele of Runx2 was found in patients with cleidocranial dysplasia, a skeletal disorder (Lee et al. 1997, Mundlos et al. 1997). A similar phenotype was observed in mice with a mutation in one allele of this gene (Otto et al. 1997). Transgenic mice with a dominant-negative form of Runx2 exhibited transient osteopenia, confirming the importance of Runx 2 in postnatal bone formation (Ducy et al. 1999). We expected to see an Runx2 loss-offunction phenotype in miR-23a Tg mice, if the expression of miR-23a was sufficient to inhibit Runx2 protein expression in vivo.

It has been shown that miR-23a also targets Satb2, a member of the special AT-rich binding transcription factor family, which interact with nuclear matrix attachment regions and activate transcription (Hassan et al. 2010). Of note, Satb2 directly interacts with Runx 2 to enhance its activity (Dobreva et al. 2006). Deletion of Satb2 in mice and mutations in Satb2 in humans revealed that Satb2 is involved in osteoblast differentiation and craniofacial development (Dobreva et al. 2006, Leoyklang et al. 2007, Britanova et al. 2006). Overexpression of miR-23a in MC3T3-E1 cells inhibited osteogenic differentiation by inhibiting Runx2 and Satb2 protein translation (Hassan et al. 2010, Zhang et al. 2011). Osteoblast numbers and activities in Tg mice were similar to those in WT mice, suggesting that overexpression of miR-23a did not affect osteogenic differentiation in vivo.

It was reported that the expression of miR-23a increases during osteogenesis (Hassan et al. 2010, Zhang et al. 2011). We also confirmed the induction of miR-23a in MC3T3-E1 cells, as an in vitro model of osteogenic differentiation (data not shown). It was speculated that the increased expression of miR-23a during osteogenesis attenuates the osteoblast-like activity of osteocytes in a mineralized matrix (Hassan et al. 2010). It is unclear why our in vivo data do not support the results of in vitro studies. One reason for this difference may be the vector system used to express the miRNAs. Stein's group
(Zhang et al. 2011, 2012) and Lian's group (Hassan et al. 2010) used a lentiviral vector system to express miR-23a in vitro, whereas we used a conventional plasmid vector system to generate Tg mice.

Another possibility is that the mild phenotype of the $\mathrm{Tg}$ mice arises from insufficient transgene expression. The expression of mature miR-23a in our $\mathrm{Tg}$ mice was about two times higher than that in WT littermates, while the expression of pri-miR-23a was much higher in $\mathrm{Tg}$ mice. We used an expression vector containing the chicken $\beta$-actin promoter and cytomegalovirus enhancer, a $\beta$-actin intron, and a bovine globin poly-adenylation signal to drive pre-miR-23a expression. This construct was used to generate $\mathrm{Tg}$ mice that express the target transgene throughout the body, and expression was maintained from pre-implantation of the embryo to adulthood (Okabe et al. 1997). It should also be noted that, although we used conventional mice to induce miR-23a expression and gain overall control of its expression, we are unable to rule out the possibility that other regulatory factors acted in a compensatory manner.

\section{Conflict of Interest}

There is no conflict of interest.

\section{Acknowledgements}

We thank Akisa Tobimatsu (The University of Tokyo) for her excellent technical support. This study was supported in part by Grants-in Aid for Young Investigators (A) (21680049 to T. A.), Scientific Research B (25282198 to T. A.) and Scientific Research A (22240058 to T. U.) from the Ministry of Education, Culture, Sports, Science and Technology, Japan. J. P. and S. W. were supported by fellowships from the Japan Society for the Promotion of Science.

\section{Abbreviations}

ALP, alkaline phosphatase miRNA, microRNA

Runx2, Runt-related transcription factor 2

Satb2, Special AT-rich sequence-binding protein 2

Tg, transgenic

TRAP, tartrate-resistant acid phosphatase

UTR, untranslated region

WT, wild-type

\section{References}

BARTEL DP: MicroRNAs: target recognition and regulatory functions. Cell 136: 215-233, 2009. 
BESSEY OA, LOWRY OH, BROCK MJ: A method for the rapid determination of alkaline phosphatase with five cubic millimeters of serum. J Biol Chem 164: 321-329, 1946.

BRITANOVA O, DEPEW MJ, SCHWARK M, THOMAS BL, MILETICH I, SHARPE P, TARABYKIN V: Satb2 haploinsufficiency phenocopies 2q32-q33 deletions, whereas loss suggests a fundamental role in the coordination of jaw development. Am J Hum Genet 79: 668-678, 2006.

DOBREVA G, DAMBACHER J, GROSSCHEDL R: SUMO modification of a novel MAR-binding protein, SATB2, modulates immunoglobulin mu gene expression. Genes Dev 17: 3048-3061, 2003.

DOBREVA G, CHAHROUR M, DAUTZENBERG M, CHIRIVELLA L, KANZLER B, FARIÑAS I, KARSENTY G, GROSSCHEDL R: SATB2 is a multifunctional determinant of craniofacial patterning and osteoblast differentiation. Cell 125: 971-986, 2006.

DUCY P, STARBUCK M, PRIEMEL M, SHEN J, PINERO G, GEOFFROY V, AMLING M, KARSENTY G: A Cbfa1-dependent genetic pathway controls bone formation beyond embryonic development. Genes Dev 13: 1025-1036, 1999.

ENOMOTO H, ENOMOTO-IWAMOTO $\mathrm{M}$, IWAMOTO $\mathrm{M}$, NOMURA S, HIMENO M, KITAMURA Y, KISHIMOTO T, KOMORI T: Cbfa1 is a positive regulatory factor in chondrocyte maturation. $J$ Biol Chem 275: 8695-8702, 2000.

GAUR T, HUSSAIN S, MUDHASANI R, PARULKAR I, COLBY JL, FREDERICK D, KREAM BE, VAN WIJNEN AJ, STEIN JL, STEIN GS, JONES SN, LIAN JB: Dicer inactivation in osteoprogenitor cells compromises fetal survival and bone formation, while excision in differentiated osteoblasts increases bone mass in the adult mouse. Dev Biol 340: 10-21, 2010.

GEOFFROY V, KNEISSEL M, FOURNIER B, BOYDE A, MATTHIAS P: High bone resorption in adult aging transgenic mice overexpressing cbfa1/runx2 in cells of the osteoblastic lineage. Mol Cell Biol 22: 6222-6233, 2002.

HARADA S, TOMINARI T, MATSUMOTO C, HIRATA M, TAKITA M, INADA M, MIYAURA C: Nobiletin, a polymethoxy flavonoid, suppresses bone resorption by inhibiting NFאB-dependent prostaglandin E synthesis in osteoblasts and prevents bone loss due to estrogen deficiency. J Pharmacol Sci 115: 89-93, 2011.

HARFE BD, MCMANUS MT, MANSFIELD JH, HORNSTEIN E, TABIN CJ: The RNaseIII enzyme Dicer is required for morphogenesis but not patterning of the vertebrate limb. Proc Natl Acad Sci U S A 102: 10898-10903, 2005.

HASSAN MQ, GORDON JA, BELOTI MM, CROCE CM, VAN WIJNEN AJ, STEIN JL, STEIN GS, LIAN JB: A network connecting Runx2, SATB2, and the miR-23a 27a 24-2 cluster regulates the osteoblast differentiation program. Proc Natl Acad Sci U S A 107: 19879-19884, 2010.

HILDEBRAND T, RÜEGSEGGER P: Quantification of bone microarchitecture with the structure model index. Comput Methods Biomech Biomed Engin 1: 15-23, 1997.

HIRUMA Y, TSUDA E, MAEDA N, OKADA A, KABASAWA N, MIYAMOTO M, HATTORI H, FUKUDA C: Impaired osteoclast differentiation and function and mild osteopetrosis development in Siglec-15-deficient mice. Bone 53: 87-93, 2013.

JIANG J, LEE EJ, GUSEV Y, SCHMITTGEN TD: Real-time expression profiling of microRNA precursors in human cancer cell lines. Nucleic Acids Res 33: 5394-5403, 2005.

KOBAYASHI T, LU J, COBB BS, RODDA SJ, MCMAHON AP, SCHIPANI E, MERKENSCHLAGER M, KRONENBERG HM: Dicer-dependent pathways regulate chondrocyte proliferation and differentiation. Proc Natl Acad Sci U S A 105: 1949-1954, 2008.

KOMORI T, YAGI H, NOMURA S, YAMAGUCHI A, SASAKI K, DEGUCHI K, SHIMIZU Y, BRONSON RT, GAO YH, INADA M, SATO M, OKAMOTO R, KITAMURA Y, YOSHIKI S, KISHIMOTO T: Targeted disruption of $\mathrm{Cbfa} 1$ results in a complete lack of bone formation owing to maturational arrest of osteoblasts. Cell 89: 755-764, 1997.

LAU KH, ONISHI T, WERGEDAL JE, SINGER FR, BAYLINK DJ: Characterization and assay of tartrate-resistant acid phosphatase activity in serum: potential use to assess bone resorption. Clin Chem 33: 458-462, 1987. 
LEE B, THIRUNAVUKKARASU K, ZHOU L, PASTORE L, BALDINI A, HECHT J, GEOFFROY V, DUCY P, KARSENTY G: Missense mutations abolishing DNA binding of the osteoblast-specific transcription factor OSF2/CBFA1 in cleidocranial dysplasia. Nat Genet 16: 307-310, 1997.

LEE Y, KIM M, HAN J, YEOM KH, LEE S, BAEK SH, KIM VN: MicroRNA genes are transcribed by RNA polymerase II. EMBO J 23: 4051-4060, 2004.

LEOYKLANG P, SUPHAPEETIPORN K, SIRIWAN P, DESUDCHIT T, CHAOWANAPANJA P, GAHL WA, SHOTELERSUK V: Heterozygous nonsense mutation SATB2 associated with cleft palate, osteoporosis, and cognitive defects. Hum Mutat 28: 732-738, 2007.

LI H, XIE H, LIU W, HU R, HUANG B, TAN YF, XU K, SHENG ZF, ZHOU HD, WU XP, LUO XH: A novel microRNA targeting HDAC5 regulates osteoblast differentiation in mice and contributes to primary osteoporosis in humans. J Clin Invest 119: 3666-3677, 2009.

LIAN JB, STEIN GS, VAN WIJNEN AJ, STEIN JL, HASSAN MQ, GAUR T, ZHANG Y: MicroRNA control of bone formation and homeostasis. Nat Rev Endocrinol 8: 212-227, 2012.

LOWRY OH, ROSEBROUGH NJ, FARR AL, RANDALL RJ: Protein measurement with the folin phenol reagent. J Biol Chem 193: 265-275, 1951.

MUNDLOS S, OTTO F, MUNDLOS C, MULLIKEN JB, AYLSWORTH AS, ALBRIGHT S, LINDHOUT D, COLE WG, HENN W, KNOLL JH, OWEN MJ, MERTELSMANN R, ZABEL BU, OLSEN BR: Mutations involving the transcription factor CBFA1 cause cleidocranial dysplasia. Cell 89: 773-779, 1997.

OKABE M, IKAWA M, KOMINAMI K, NAKANISHI T, NISHIMUNE Y: 'Green mice' as a source of ubiquitous green cells. FEBS Lett 407: 313-319, 1997.

OSKOWITZ AZ, LU J, PENFORNIS P, YLOSTALO J, MCBRIDE J, FLEMINGTON EK, PROCKOP DJ, POCHAMPALLY R: Human multipotent stromal cells from bone marrow and microRNA: regulation of differentiation and leukemia inhibitory factor expression. Proc Natl Acad Sci U S A 105: 18372-18377, 2008.

OTTO F, THORNELL AP, CROMPTON T, DENZEL A, GILMOUR KC, ROSEWELL IR, STAMP GW, BEDDINGTON RS, MUNDLOS S, OLSEN BR, SELBY PB, OWEN MJ: Cbfa1, a candidate gene for cleidocranial dysplasia, is essential for osteoblast differentiation and bone development. Cell 89: 765-771, 1997.

RUSSELL AP, WADA S, VERGANI L, HOCK MB, LAMON S, LÉGER B, USHIDA T, CARTONI R, WADLEY GD, HESPEL P, KRALLI A, SORARU G, ANGELINI C, AKIMOTO T: Disruption of skeletal muscle mitochondrial network genes and miRNAs in amyotrophic lateral sclerosis. Neurobiol Dis 49: 107-117, 2013.

SOLTANOFF CS, YANG S, CHEN W, LI YP: Signaling networks that control the lineage commitment and differentiation of bone cells. Crit Rev Eukaryot Gene Expr 19: 1-46, 2009.

SUDO H, KODAMA HA, AMAGAI Y, YAMAMOTO S, KASAI S: In vitro differentiation and calcification in a new clonal osteogenic cell line derived from newborn mouse calvaria. J Cell Biol 96: 191-198, 1983.

WADA S, KATO Y, OKUTSU M, MIYAKI S, SUZUKI K, YAN Z, SCHIAFFINO S, ASAHARA H, USHIDA T, AKIMOTO T: Translational suppression of atrophic regulators by microRNA-23a integrates resistance to skeletal muscle atrophy. J Biol Chem 286: 38456-38465, 2011.

ZHANG Y, XIE RL, CROCE CM, STEIN JL, LIAN JB, VAN WIJNEN AJ, STEIN GS: A program of microRNAs controls osteogenic lineage progression by targeting transcription factor Runx2. Proc Natl Acad Sci US A 108: 9863-9868, 2011.

ZHANG Y, XIE RL, GORDON J, LEBLANC K, STEIN JL, LIAN JB, VAN WIJNEN AJ, STEIN GS: Control of mesenchymal lineage progression by microRNAs targeting skeletal gene regulators Trps1 and Runx2. J Biol Chem 287: 21926-21935, 2012. 